Vol. 5 No. 4 (2021) pp. 503 - 510

Available online at: http://jurnal.umpwr.ac.id/index.php/abdimas/index

p-ISSN: $\underline{2580-3492}$ e-ISSN: $\underline{2581-0162}$

\title{
Rumah Siap Kerja: English For Jobseekers Pelatihan Bahasa Inggris Daring Untuk Persiapan Mencari Kerja di Masa PHK Massal Saat Pandemi Covid-19
}

\section{Ince Dian Apriliyani Azir $ه$}

\section{Politeknik Negeri Media Kreatif}

Jl. Srengseng Sawah, Jagakarsa, Jakarta Selatan, Indonesia

| incedian@polimedia.ac.id $₫$ | DOI : https://doi.org/10.37729/abdimas.v5i4.1331 |

\begin{abstract}
Abstrak
Tingginya angka pengangguran saat pandemi Covid-19 melanda Indonesia dan dunia merupakan dasar ide pengabdian masyarakat ini dilakukan. Meningkatnya angka pengangguran ini sebagai dampak dari banyaknya pekerja yang dirumahkan dan pemutusan hubungan kerja (PHK). Rumah Siap Kerja telah banyak menyelenggarakan pelatihan keterampilan dalam upaya menambah kualitas sumber daya manusia. Harapannya, agar angka pengangguran bisa diturunkan melalui keterampilan yang diberikan selama pelatihan. Penulis menginisiasi kegiatan pelatihan secara daring ini sebagai solusi persiapan mencari kerja yang membekali peserta pengetahuan praktis dalam berkomunikasi Bahasa Inggris secara tertulis dan secara lisan. Para peserta dalam pelatihan daring ini dibekali pemahaman terkait tata cara penulisan lamaran kerja yang tidak hanya tertulis tetapi juga secara elektronik. Tak sekedar persiapan dokumen kerja tertulis yang diperoleh peserta selama pelatihan, peserta juga mengikuti simulasi wawancara kerja dalam Bahasa Inggris. Hasil akhir dari pelatihan ini menunjukkan antusiasme dan umpan balik positif dimana peserta mengalami peningkatan keterampilan komunikasi berbahasa Inggris yang dibutuhkan saat proses pencarian dan rekrutmen pekerja walaupun digelar secara daring di masa pandemi.
\end{abstract}

Kata Kunci: Pelatihan, Bahasa Inggris, Pandemi, Daring

(i) (8) This work is licensed under a Creative Commons Attribution-NonCommercial 4.0 International License

\section{Pendahuluan}

Berdasarkan proyeksi dari Suhariyanto selaku Kepala Badan Pusat Statistik, jika pandemi Covid-19 bisa segera berakhir, paling tidak sesuai dengan yang diasumsikan oleh Badan Nasional Penanganan Bencana (BNPB) yaitu sekitar tanggal 29 Mei 2020, maka persentase penggangguran kemungkinan bisa mencapai target hanya pada level 4,8\%-5\%. Akan tetapi, jika prediksi periode tercepat ini tidak terjadi, maka target level ini tidak akan mungkin dicapai (Anjaeni, 2021). Rumah Siap Kerja dengan visi menekan angka pengangguran melalui berbagai program (Azir, 2019) termasuk berbagai pelatihan peningkatan keterampilan ini hadir sebagai salah satu solusi alternatif mencapai target penekanan angka pengangguran. Sebelum pandemi, pelatihan di Rumah Siap Kerja diadakan secara luring. Sejak pandemi Covid-19 melanda Indonesia dan dunia, semua kegiatan Rumah Siap Kerja dialihkan ke metode pelatihan secara daring. 
Berbagai pelatihan daring diadakan untuk meningkatkan keterampilan para pencari kerja di masa pandemi. Salah satu keterampilan yang menjadi kualifikasi wajib pekerjaan yang relatif lebih baik dengan indikator jumlah penghasilan yang lebih tinggi adalah keterampilan berkomunikasi secara tertulis dan lisan dalam bahasa Inggris. Terbukti banyak penelitian yang memaparkan bahwa keterampilan inti yang wajib dimiliki agar unggul di hampir semua level kehidupan manusia adalah kemampuan berbahasa Inggris (Aungwatanakun, 1994; Al-Sibai, 2004; Richard, 2008; Rahmawaty, \& Milaningrum, 2019; Azir, 2019). Hal ini juga terlihat dalam transaksi global dimana para pekerja wajib berbahasa Inggris untuk memudahkan kegiatan transaksi antarsatu negara (Azir, 2019).

Untuk itu, kegiatan pelatihan secara daring di masa pandemi ini diadakan untuk sebagai solusi dalam meningkatkan kemampuan berbahasa Inggris peserta baik secara lisan maupun tulisan. Karena keterampilan berbahasa Inggris yang diperlukan dalam dunia profesional dan dunia akademik relatif sedikit berbeda, maka pelatihan ini lebih banyak berfokus kepada aspek materi bahasa Inggris di dunia profesional sehingga memungkinkan peserta memperoleh pekerjaan yang mewajibkan bahasa Inggris di berbagai jenis industri, mulai dari industri skala menengah hingga skala besar, tidak hanya level nasional tetapi juga multinasional.

Untuk meningkatkan kesempatan mendapatkan pekerjaan di perusahaan yang bonafide, kegiatan pelatihan ini membekali peserta dalam hal pembuatan profil dalam bahasa Inggris. Kegiatan pembekalan ini bertujuan untuk memetakan dan mendeskripsikan apa yang dimiiki oleh peserta dalam dirinya masing-masing. Peserta wajib mengetahui dan mendeskripsikan kompetensi umum, kompetensi khusus bidang masing-masing, keterampilan yang dimiliki, hingga profil keahlian para peserta. Penulisan profil diri ini dilakukan secara manual dalam bentuk CV dan juga secara elektronik dalam bentuk profil diri yang dipasang di media sosial profesional Linked In. Selain itu, para peserta juga dilatih untuk memperhatikan tata cara berbahasa dan beretika dalam menulis surat lamaran kerja baik dalam bentuk surat tertulis maupun dalam bentuk surat elektronik.

Berdasarkan hasil penelitian yang dipaparkan oleh Lie (2007); Di Grapello, Kruse, \& Tandon (2011); Handayani (2016); Sushy \& Rachel (2018); Damayanti (2019) dan Azir (2019), di dunia kerja dibutuhkan karyawan yang terampil yang terampil sesuai bidang masing-masing dan juga terampil dalam bidang komunikasi Bahasa Inggris. Oleh karena itu, pelatihan daring ini tidak hanya mencakup pelatihan keterampilan komunikasi lisan tetapi juga membekali peserta dalam hal keterampilan menghasilkan tulisan dalam Bahasa Inggris. Para peserta dibekali informasi tentang tips dan trik menghadapi wawancara kerja berbahasa Inggris. Tips dan trik ini sangat bermanfaat bagi para peserta terutama dalam hal meningkatkan kesempatan diterima di industri atau perusahaan yang dilamar oleh para peserta.

Hasil akhir dari pelatihan daring ini diharapkan dapat meningkatkan keterampilan para peserta untuk memperoleh pekerjaan yang lebih baik seiring dengan peningkatan kemampuan komunikasi berbahasa Inggris yang dibutuhkan saat proses pencarian dan rekrutmen pekerja. Pelatihan ini diharapkan mampu memperbesar peluang para pencari kerja untuk diterima bekerja di perusahaan yang diimpikan berbekal keterampilan komunikasi berbahasa Inggris yang meningkat selama kegiatan. 


\section{Metode}

Metode yang digunakan dalam kegiatan daring melalui platform Zoom meeting ini lebih banyak ke praktek dibandingkan teori, jika dialokasikan dalam bentuk persen menjadi $20 \%$ presentasi yang berisi teori oleh pengabdi sebagai narasumber. Kemudian, sisanya diisi dengan $80 \%$ praktek berupa simulasi yang dilakukan oleh para peserta. Metode pelatihan dibagi ke dalam beberapa bentuk seperti:

\subsection{Presentasi Teori}

Kegiatan pelatihan keterampilan bahasa Inggris secara daring ini dimulai dengan perkenalan antara narasumber dengan para peserta sebelum pemateri mempresentasikan tata cara membuat profil dalam bahasa Inggris. Profil yang dimaksud adalah profil yang sepersonal mungkin sehingga bisa menjadi ciri calon pekerja untuk menarik perhatian dan minat penyedia lapangan kerja. Hal ini penting dikarenakan para pemberi kerja berdasarkan data dari berbagi sumber menyebutkan bahwa rata-rata hanya mempunyai 8 detik untuk menyeleksi para pelamar kerja. Oleh karena itu, pemateri menginformasikan cara membuat profil diri yang menarik yang tidak hanya secara tata bahasa Inggris yang benar maupun secara diksi yang tetap memperhatikan etika komunikasi. Materi yang dipresentasikan tidak hanya mencakup profil diri dalam bentuk CV yang ditulis di atas kertas maupun di media elektronik daring. Materi yang dipresentasikan lainnya juga mencakup kebutuhan peserta dalam melamar pekerjaan seperti surat lamaran yang patut dicontoh.

\subsection{Praktek Simulasi}

Bobot kegiatan praktek lebih banyak dilakukan selama pelatihan daring ini berlangsung agar para peserta mendapatkan manfaat maksimal setelah pelatihan. Dengan berbekal pemaparan teori sebelumnya, para peserta langsung mempraktekkan cara membuat CV yang menarik dan informatif. Setelah itu, para peserta diarahkan untuk membuat profil diri secara daring melalui media sosial apa saja, terutama media sosial yang memang diperuntukkan untuk tujuan profesional seperti Linked In. Setelah praktek pembuatan profil diri selesai, para peserta kemudian dilatih untuk menulis surat lamaran kerja mengikuti tata cara dan gaya penulisan yang dipaparkan sebelumnya.

Peserta diarahkan untuk praktek menulis surat lamaran kerja dalam bahasa Inggris melalui aplikasi Microsoft Word dan laman penyedia template surat lamaran kerja yang sudah distandarisasi dan diakui banyak instansi. Peserta tidak hanya diberikan bekal keterampilan teknis tetapi juga etika dalam penulisan sehingga hasil bisa lebih maksimal (Azir, 2019). Kegiatan selanjutnya setelah semua amunisi untuk melamar kerja dituntaskan, para peserta kemudian berlatih menjawab beberapa daftar pertanyaan yang seringkali ditanyakan oleh pemberi kerja saat sesi wawancara kerja. Semua daftar pertanyaan sudah diberikan sebelumnya oleh pemateri disertai dengan contoh jawaban yang bisa menginspirasi peserta dalam mengisi jawaban sesuai kondisi dan situasi masing-masing. Setelah peserta selesai mengisi jawaban di kolom daftar pertanyaan yang sering muncul di sesi wawancara kerja, setiap peserta melakukan simulasi wawancara dengan pemateri sehingga memaksimalkan pengalaman peserta dalam wawancara kerja berbahasa Inggris 


\section{Hasil dan Pembahasan}

Kegiatan pelatihan Bahasa Inggris secara daring ini dilaksanakan sebagai bentuk pengabdian kepada masyarakat yang menjadi korban dampak pandemi Covid-19 dimana mereka dirumahkan bahkan mengalami pemutusan hubungan kerja (PHK) maupun selama pandemi Covid-19. Rumah Siap Kerja sebagai mitra pengabdi sejak awal berdirinya memang fokus kepada pengurangan angka pengangguran dan persiapan kaum muda untuk mencari kerja dalam bentuk berbagai pelatihan. Banyak pelatihan berbasis keterampilan berbahasa asing yang sudah dilaksanakan oleh Rumah Siap Kerja. Pelatihan bahasa Inggris yang berfokus kepada keterampilan dalam mencari kerja sebelumnya juga sudah dilaksanakan secara luring oleh pengabdi. Akan tetapi, sejak pandemi, seluruh kegiatan dibatasi sesuai aturan pemerintah dalam menangani pandemi. Sehingga, seluruh kegiatan pelatihan yang tadinya tatap muka secara luring dialihkan menjadi kegiatan daring melalui aplikasi konferensi. Salah satu bentuk kegiatan pada Rumah Siap Kerja disajikan dalam bentuk poster pada Gambar 1.

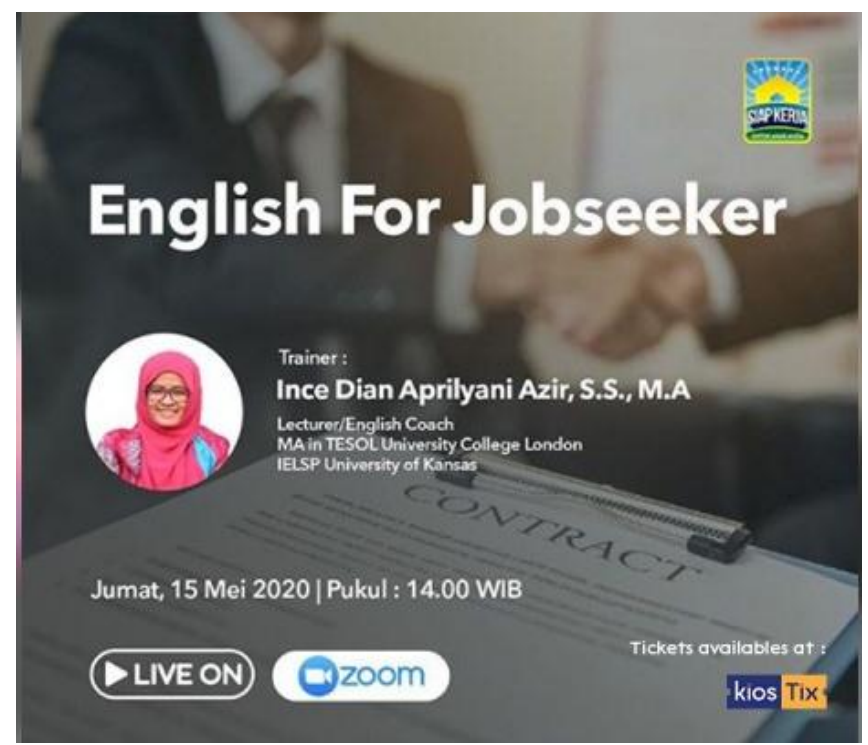

Gambar 1. Poster publikasi kegiatan pelatihan

Kegiatan ini dilaksanakan secara daring sehingga peserta yang hadir dalam pelatihan ini datang dari berbagai wilayah Indonesia. Para peserta yang ikut dalam pelatihan ini sebelumnya wajib mendaftar melalui laman Ruang Siap Kerja dengan mengisi beberapa data diri. Mayoritas peserta adalah kaum muda yang dirumahkan atau kehilangan pekerjaan sejak masa pandemi yang banyak membatasi kegiatan di luar rumah. Hampir semua peserta mengikuti pelatihan ini dengan motivasi ingin meningkatkan kemampuan dan keterampilan diri dalam berbahasa Inggris agar bisa segera memperoleh peluang kerja lebih baik lagi, terutama di masa pandemi. Beberapa peserta mengakui bahwa kesempatan pelatihan daring yang berfokus kepada keterampilan mencari peluang kerja ini jarang ditemui. 
Secara umum, kegiatan pelatihan ini terselenggara dengan baik dan lancar hingga akhir. Peserta yang mengikuti sesi daring ini terlihat antusias dan aktif sejak pertama kali bergabung dalam ruang Zoom meeting yang disiapkan oleh Rumah Siap Kerja sebagai mitra pengabdi. Antusiasme peserta sejak awal terlihat saat mereka hadir awal waktu bahkan mayoritas sudah hadir sebelum pelatihan daring ini dimulai. Selama sesi presentasi teori berlangsung, para peserta juga aktif bertanya ketika ada hal yang masih dirasa kurang jelas dan butuh penjelasan yang lebih rinci lagi, seperti disajikan pada Gambar 2.

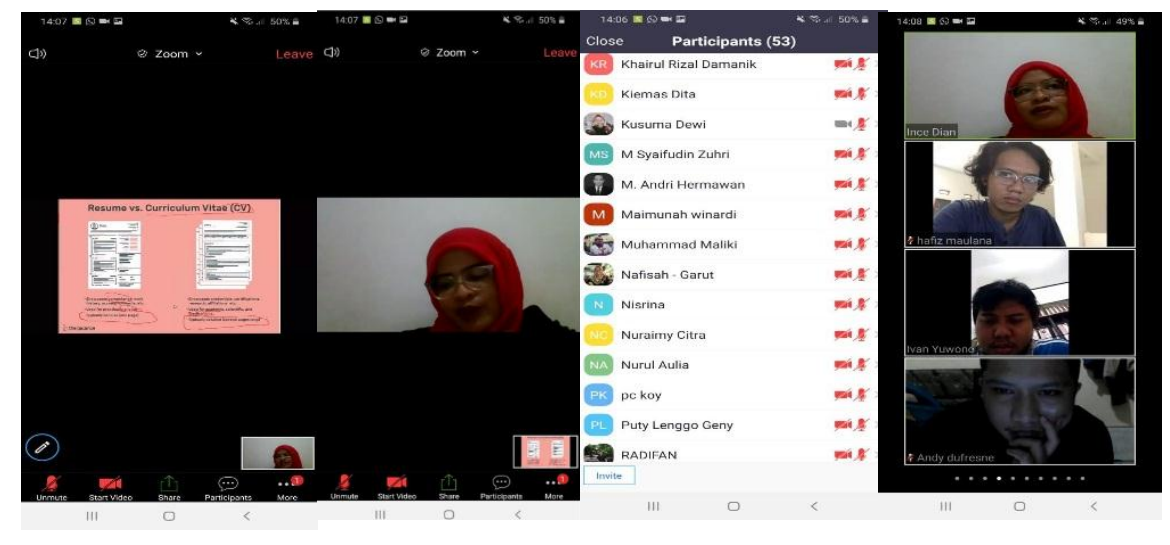

Gambar 2. Pelatihan bahasa Inggris Daring

Kegiatan pelatihan lebih banyak diisi dengan simulasi praktis agar peserta bisa memperoleh ilmu dan keterampilan maksimal meski secara jarak jauh lewat media komunikasi daring ini. Simulasi praktis yang dilakukan dimulai dari menulis profil diri dalam bentuk CV di file yang sudah disediakan hingga menulis CV di laman penyedia informasi kerja yang terpercaya, seperti Gambar 3.



Gambar 3. Contoh dan template CV Europass 
Pemateri juga sebisa mungkin menjelaskan terkait data privasi apa saja yang tidak boleh ditulis peserta di dalam profil diri baik di media konvensional maupun di media elektronik. Hal ini terkait keamanan data pribadi dan pencegahan dari penyalahgunaan data pribadi. Setelah memahami dan mempraktekkan cara membuat profil diri, peserta diarahkan untuk menulis surat lamaran kerja sesuai template yang sudah dibagikan dan dijelaskan oleh pemateri sebelum sesi praktek dimulai. Peserta melakukan simulasi disertai bimbingan dari pemateri langkah demi langkahnya agar peserta bisa memahami tata cara dan etika berkomunikasi tertulis secara profesional dimulai dari bagian pendahuluan, isi, dan penutup surat lamaran. Penulisan surat lamaran diisi sesuai petunjuk file yang dibagikan oleh pemateri. Selain itu, peserta juga diarahkan untuk menulis surat lamaran kerja berbasis laman penyedia kerja secara elektronik untuk memperbesar peluang mendapatkan pekerjaan yang lebih baik.

Tahap setelah dokumen dalam mencari kerja jadi, para peserta harus bisa menjawab daftar pertanyaan yang sering muncul pada tahap wawancara kerja berbahasa Inggris. Contoh jawaban untuk setiap pertanyaan juga sudah dijelaskan dan diperlihatkan secara tertulis di dalam boring petunjuknya. Peserta bisa langsung menjawab sesuai dengan situasi dan kondisi masing-masing. Setelah mengisi borang pertanyaan wawancara, peserta akan melakukan simulasi praktek wawancara dalam Bahasa Inggris bersama dengan pemateri yang bertindak sebagai interviewer pemberi kerja. Peserta lain menyiapkan diri dan ikut mengevaluasi serta memberikan komentar dan umpan balik terhadap peserta yang melakukan simulasi wawancara ini. Para peserta tetap antusias di sesi akhir simulasi ini, sehingga waktu yang disediakan tidak cukup untuk melakukan simulasi dengan semua peserta yang hadir. Para peserta yang tidak memperoleh kesempatan untuk melakukan simulasi wawancara berharap agar pelatihan daring ini bisa terlaksana kembali agar mereka bisa tetap ikut berpartisipasi dalam simulasi.

Tahap akhir dari pelatihan ini adalah evaluasi oleh pemateri dan dilanjutkan dengan umpan balik dari para peserta. Seluruh peserta mengapresiasi dan berterima kasih atas pelatihan daring ini karena dinilai sangat bermanfaat untuk mereka terutama dalam memperoleh kesempatan pekerjaan yang lebih baik tidak hanya di masa sekarang tetapi juga di masa mendatang. Peserta mengevaluasi beberapa poin kelebihan dari pelatihan daring ini misalnya dalam hal efektivitas materi, efisiensi waktu, jangkauan yang lebih luas, dan metode yang interaktif. Meski demikian, sebagian peserta mengakui bahwa metode tatap muka secara luring akan lebih baik dan lebih efektif dibanding metode daring seperti ini. Hal ini dikarenakan beberapa kendala yang dihadapi peserta terutama dalam hal konektivitas internet yang kurang stabil di beberapa daerah, juga termasuk peserta yang mengeluhkan mati listrik di tengah-tengah sesi sehingga tidak mengikuti materi secara penuh. Beberapa kendala ini tidak menyurutkan minat dan semangat peserta dalam mengikuti pelatihan dan menyelesaikan tugas simulasi karena dinilai sebagai bekal yang bermanfaat untuk para peserta. Oleh karena itu, di masa pandemi sekarang ini, seluruh peserta berharap agar pelatihan keterampilan berbahasa Inggris dalam mencari kerja ini bisa terus dilaksanakan secara daring maupun jika memungkinkan dilaksanakan secara luring agar lebih interaktif antara satu peserta dengan peserta lainnya karena metode daring para peserta harus bergantian saat berbicara karena tidak memungkinkan adanya diskusi secara bersamaan di dalam aplikasi konferensi daring. 


\section{Kesimpulan}

Kegiatan pelatihan Bahasa Inggris yang terselenggara secara daring dengan tujuan untuk persiapan peserta pelatihan mencari kerja di tengah tingginya angka pemutusan hubungan kerja (PHK) massal selama masa pandemi Covid-19 ini. Keseluruhan materi yang diajarkan kepada peserta dinilai sangat bermanfaat untuk bekal di masa sekarang dan di masa yang akan datang ketika tawaran pekerjaan sudah mulai dibuka. Kegiatan pelatihan daring yang banyak ditekankan ke metode praktis dari penerapan teori yang sudah dipaparkan sebelumnya ini dinilai aplikatif oleh para peserta. Meski demikian, sebagian peserta mengakui bahwa metode tatap muka secara luring dinilai akan lebih baik dan lebih efektif dibanding metode daring dengan segala keterbatasan dan tantangan yang dihadapi masing-masing peserta. Akan tetapi, di masa pandemi sekarang ini, seluruh peserta menyarankan agar pelatihan keterampilan berbahasa Inggris dalam mencari kerja ini bisa terus dilaksanakan secara daring maupun jika memungkinkan dilaksanakan secara luring agar lebih interaktif antara satu peserta dengan peserta lainnya karena metode daring para peserta harus bergantian saat berbicara karena tidak memungkinkan adanya diskusi secara bersamaan di dalam aplikasi konferensi daring.

\section{Daftar Pustaka}

Al-Sibai, D. (2004). Promoting oral fluency of second language learners. Retrieved on October, 13.

Anjaeni, Rahma. (2021). "BPS: Jika corona berakhir Mei 2020, target tingkat pengangguran 5\% bisa tercapai", https://nasional.kontan.co.id/news/bps-jikacorona-berakhir-mei-2020-target-tingkat-pengangguran-5-bisa-tercapai , diakses pada 9 September 2020 pukul 14.05.

Aungwatanakun, S. (1994) English Teaching Methodology, (2nd), Bangkok: Chulalongkorn University Press.

Azir, I. D. A. (2019). A Model for Scaffolding Academic IELTS Writing Task 2: MMPIPE. Indonesian EFL Journal: Journal of ELT, Linguistics, and Literature, 5(2), 45-54.

Azir, I. D. A. (2019). Applying Peer Scaffolding to Enhance the EFL Vocational Students' Speaking Skills. Ethical Lingua: Journal of Language Teaching and Literature, 6(2), 149-157.

Azir, I. D. A. (2019). English for Jobseekers: Pelatihan Keterampilan Berbahasa Inggris untuk Anak Muda Pencari Kerja di Rumah Siap Kerja Jakarta. Jurnal Surya Masyarakat, 2(1), 20-28.

Damayanti, L. S. (2019, December). Menilik Peranan Dan Pentingnya Keterampilan Berbahasa Inggris Dalam Industri Pariwisata. In Journey (Journal of Tourismpreneurship, Culinary, Hospitality, Convention and Event Management) (Vol. 2, No. 1, pp. 71-82).

Di Gropello, E., Kruse, A., \& Tandon, P. (2011). Skills for the labor market in Indonesia: trends in demand, gaps, and supply. The World Bank. 
Handayani, S. (2016). Pentingnya kemampuan berbahasa Inggris sebagai dalam menyongsong ASEAN Community 2015. Jurnal Profesi Pendidik, 3(1), 102-106.

Lie, A. (2007). Education policy and EFL curriculum in Indonesia: Between the commitment to competence and the quest for higher test scores. TEFLIN journal, 18(1), 01-15.

Rahmawaty, P., \& Milaningrum, E. (2019). Kesiapan Kerja dan Kemampuan Berbahasa Inggris pada Mahasiswa Politeknik Negeri Balikpapan dalam Menghadapi Revolusi Industri 4.0. Eksistensi, 1(2).

Richards, J. C. (2008). Teaching listening and speaking. Cambridge, England: Cambridge University press.

Sushy, S., \& Rachel, R. (2018). Analisis Kebutuhan Keterampilan Berbahasa Inggris Mahasiswa Jurusan Manajemen Fakultas Ekonomi Universitas Kristen Indonesia Toraja. Jurnal Keguruan dan Ilmu Pendidikan, 6(3), 205-210. 